\title{
The effect of dissolved oxygen on common carp (Cyprinus carpio) and basil (Ocimum basilicum) in the aquaponics system
}

\author{
Dávid Homoki ${ }^{4}$ - Toviho Odunayo ${ }^{2}$ - Dániel Minya ${ }^{4}$ - László Kovács ${ }^{4}$ - Judit Lelesz ${ }^{2}$ - Péter Bársony ${ }^{2}$ - \\ Milán Fehér ${ }^{2}$ - György Kövics ${ }^{3}$ - László Stündl ${ }^{1}$ \\ ${ }^{1}$ Insitute of Food Technology, Debrecen, Hungary \\ ${ }^{2}$ University of Debrecen, Faculty of Agricultural and Food Sciences and Environmental Management \\ Institute of Animal Science, Biotechnology and Nature Conservation, Debrecen, Hungary \\ ${ }^{3}$ Institute of Plant Protection, Debrecen, Hungary \\ ${ }^{4}$ University of Debrecen, Doctoral School of Animal Science \\ homokidz@agr.unideb.hu
}

\section{SUMMARY}

\begin{abstract}
Aquaponics is an integrated system that combines fish farming (aquaculture) and hydroponic plant production. The objective of this study was to examine how the level of dissolved oxygen with or without an air pump affects water quality, fish output and plant growth parameters for common carp (Cyprinus carpio) and basil (Ocimum basilicum).

Ebb - and flood aquaponics systems (with automatic syphon) was used. Two treatments were set in this experiment, one of which was the aquaponics system without air pump (unit I), where water of the plant bed was pumped two directions, one falling back to the fish tank oxygenating the water the other was pumped to the hydroponics unit. The other system (unit II) was designed with an air pump.

In the course of the study, water quality parameters, such as oxygen saturation, dissolved oxygen (DO), electrical conductivity (EC) and nitrite were significantly different ( $p<0.05)$. Total basil biomass was higher in unit II. (5367.41 g). The final biomass of common carp were $2829.45 \mathrm{~g} \pm 79.24$ and $2980.6 \mathrm{~g} \pm 64.13 \mathrm{~g}$ in unit I and unit II respectively. Weight gain (WG) and specific growth rate (SGR) showed no significant differences $(p>0.05)$ between the treatments.
\end{abstract}

Keywords: aquaponics; common carp; basil; flood-and-drain system; air pump

\section{INTRODUCTION}

Aquaponics is an integrated system that combines recirculating aquaculture and hydroponic plant production (Diver, 2006). A typical aquaponics consists of a fish tank (aquaculture), a biofilter (for nitrification) and a plant grow bed (hydroponics) (Love et al., 2015). The latter is practically a biological filter because the nitrogen forms are excellent nutrients for plants. Fish wastewater in an aquaponics system, is delivered to hydroponics unit where the plants use the nitrogen forms provided by nitrification. Nitrification is the main process that transforms $\mathrm{NH}_{4}{ }^{+}$to $\mathrm{NO}_{3}{ }^{-}$in the presence of oxygen (Hu et al., 2015). This process is carried out by three groups of bacteria, ammonia oxidizing bacteria (Nitrosomonas, Nitrosococcus, Nitrosospira, Nitrosolobus, Nitrosovibrio sp), ammonia oxidizing archaea and the nitrite oxidizing bacteria (Nitrobacter, Nitrococcus, Nitrospira, Nitrospina sp) (Ebeling et al., 2006; Panuvatvanich et al., 2009). Somerville et al. (2014) believed that ammonia $\left(\mathrm{NH}_{4}^{+}\right)$concentration should not reach levels above $1 \mathrm{mg} \mathrm{L}^{-1}$. The nitrite $\left(\mathrm{NO}_{2}^{-}\right)$is usually within the range s 0.4 to $1.1 \mathrm{mg} \mathrm{L}^{-1}$ in a well-operated aquaponics system. The nitrate $\left(\mathrm{NO}_{3}{ }^{-}\right)$is not toxic up to $150-300$ $\mathrm{mg} \mathrm{L}^{-1}$ (Graber and Junge, 2009; Hu et al., 2014). The concentration of nitrogen forms are the result of conversion by nitrifying bacteria which are oxygen dependent.

The oxygen is most important determinant factor of plant and fish-rearing. It is an essential element in aquaponics too, necessary for nitrification and plays critically important role in fish biomass in aquaponics production. Rakocy (2007) believed if DO level is insufficient root rot symptoms may occur therefore it is important also from a plant health point of view.

Dissolved oxygen level is influenced by many factors. The environmental factors (air temperature, light intensity, and air humidity) and water quality $(\mathrm{pH}$, water temperature, bacteria flora) are the main parameters influencing the fish water. (Kasozi et al., 2019). Dissolved oxygen (DO) optimal for the aquaponics is in the range of 4-8 $\mathrm{mg} \mathrm{L}^{-1}$. (Tyson et al., 2008). The demands of fish species will determine this value. Baßmann et al (2017) in study found that, the African Catfish (Clarias gariepinus) showed good growth parameters in aquaponics at $8 \mathrm{mg} \mathrm{L}^{-1}$ oxygen (DO)level. Tilapia (Oreochromis niloticus) do not require a high oxygen concentration because it can survive at $0.5-1.0 \mathrm{mg} \mathrm{L}^{-1}$ (El-Sayed, 2006). Another study showed that the oxygen contents of fish tanks were $6 \mathrm{mg} \mathrm{L}^{-1}$. The Nile tilapia (Oreochromis niloticus) showed also good specific growth rate (SGR) (Abentin et al., 2018). Similar parameters were reported by Hussain et al. (2015) when the effect of water flow rate on the production potential of koi carp (Cyprinus carpio var. koi) under aquaponics system was examined with specific growth rate (SGR) 1.22 $\left(\%\right.$ day $\left.^{-1}\right)$ and the dissolved oxygen $6.89\left(\mathrm{mg} \mathrm{L}^{-1}\right)$. The carp (Cyprinus carpio) is known to be tolerant to higher oxygen fluctuations in ponds between $0.5-20 \mathrm{mg} \mathrm{L}^{-1}$ (Lukowicz, 1982).

The objective of this study was to examine how the level of dissolved oxygen changes with or without an air pump and what effect it has the water quality, fish 
output and plant growth parameters for common carp (Cyprinus carpio) and basil (Ocimum basilicum).

\section{MATERIALS AND METHODS}

\section{Aquaponic systems and experimental design}

The experiment was conducted in the Fish Biology

Laboratory of University of Debrecen Faculty of Agricultural and Food Sciences and Environmental Management. Two ebb and flood aquaponics systems with auto siphon and gravel bed hydroponic were connected. The aquaponics systems (Figure 1/II.) were operated in double sheet plastic tunnel greenhouse under shade cloth. The capacity of fish tank and hydroponics unit (plant boxes) were 225 liters and 32 liters, respectively. These fish rearing tanks contained $150 \mathrm{~L}$ freshwater. Crushed stones were used as substrate in the plant boxes with the dimensions: $25 \mathrm{~cm}$ in height and surface area of $43 \mathrm{~cm}$ (width) x $75 \mathrm{~cm}$ (length). The total surface area of the hydroponics boxes of the three replicates were approx. $1 \mathrm{~m}^{2}$. The maximum flood status was $15 \mathrm{~cm}$ water level at the plant boxes. A submersible pump (capacity $1650 \mathrm{~L} \mathrm{~h}^{-1}$ ) were used to drive the water to the hydroponics units from the fish tanks There were two treatments in this experiment, one without aeration (unit I), and the other (unit II) with air pump (Air pump 400, Eheim, Germany). Water of the plant bed were split into two parts in unit I, one falling back to the fish tank providing oxygenation, and the other was pumped into the hydroponics unit (Figure 1/I.). There were three replicates for each treatment (Figure 2). The environmental factors inside the plastic greenhouse were measured daily during experiment. Light intensity was measured with a digital luxmeter (PKT-5065 Luxmeter, spectral, range: 0.1-100.000 Lux; 0.1 Lux; $\pm 4 \%$ ). The lux values were ranging between 7305 Lux and 9039 Lux e depending on the weather conditions. The air humidity (PCE-THB 40 Thermo Hygrometer Barometer) were $65.8 \%$ on average and air temperature $30.6^{\circ} \mathrm{C}$ on average. There was no water exchange, only the evaporated water was refilled once a week. The experiment was carried out in 58 days.

Figure 1. Aquaponics system
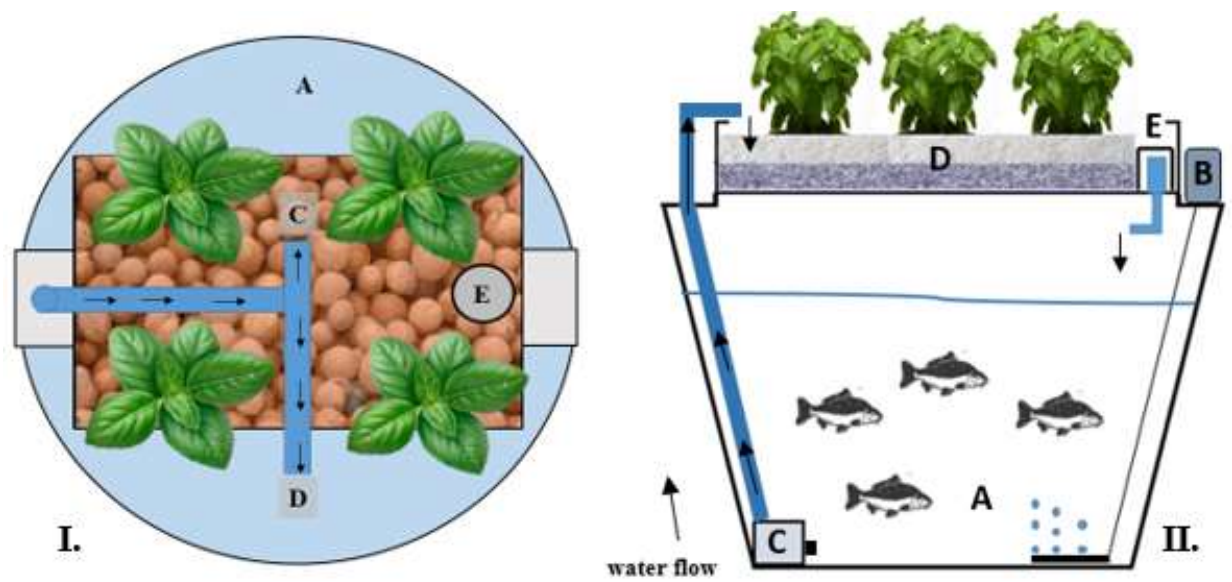

$\mathrm{I} .=$ The water division of the plant bed in unit $\mathrm{I}(\mathrm{A}=$ fish tank, $\mathrm{C}=$ water falling into the fish tank, $\mathrm{D}=\mathrm{In}$ the plant bed running water, $\mathrm{E}=$ bell siphon. II. = The structure of unit II (A = fish tank; $\mathrm{B}=$ air pump (There was not in other aquaponics system); $\mathrm{C}=$ pump; $\mathrm{D}=$ plant box; $\mathrm{E}=$ bell siphon).

\section{Fish and plant species}

Mixed sex common carp (Cyprinus carpio) was stocked in all fish rearing tanks $(\mathrm{n}=15)$. They were acclimated for 1 week before the experiment. The mean mass (or average body weight) was $140.90 \mathrm{~g}$ in unit I and $140.57 \mathrm{~g}$ in unit II $\left(8.43 \mathrm{~kg} \mathrm{~m}^{-3}\right)$. The fish were fed two times daily at 8.00 am and $4.00 \mathrm{pm}(10 \mathrm{~g} / \mathrm{fish}$ tank/ day, $1.43 \%$ of total fish biomass) with sinking carp feed (BioMar- EFICO Alpha 756), containing 40\% crude protein, $23 \%$ crude fat, and $3.9 \%$ crude fiber. The fish were weighed weekly.

Basil (Ocimum basilicum, Genovese F1) plants were chosen in the hydroponics units, because they are fast growing and have favorable nutrient uptake (Kurd et al., 2017; Mostafavi et al., 2019), also it is widely used in soilless cultures (Roosta, 2014; Mangmang et al., 2016). The basil seeds were planted in universal potting soil (Premi Vit deluxe, containing $\mathrm{N}, 1 \% \mathrm{P}_{2} \mathrm{O}_{5}$, $0.1 \% \mathrm{~K}_{2} \mathrm{O}, 0.3 \% \mathrm{pH}, 6.4( \pm 0.5)$. After this plant lets were transferred to the grow beds (initial plant biomass: $4.64 \mathrm{~g} \pm 1.7)$. The basil planting density was 12 seedlings per $3 \mathrm{~m}^{-2}$. No additional fertilizers were provided during the experiment and the plants were harvested only once at the end of experiment.

\section{Physical and chemical analysis}

Physical water parameters were measured each day in the fish tanks. Dissolved oxygen (DO, $\mathrm{mg} \mathrm{L}^{-1}$ ) oxygen $(\%)$, temperature $\left({ }^{\circ} \mathrm{C}\right)$ (Hach-Lange HQ40D, Germany) electrical conductivity (EC, $\mu \mathrm{s} \mathrm{cm}^{-1}$, Adwa 
AD332, Romania), pH (HANNA combo HI 98120, Romania), redox potential (ORP, mv, HM digital ORP200). Chemical water parameters were analyzed weekly with a spectrophotometer (Hach Lange DR 3900 , Germany) for $\mathrm{NH}_{3}-\mathrm{N}\left(\mathrm{mg} \mathrm{L}^{-1}\right), \mathrm{NO}_{2}-\mathrm{N}\left(\mathrm{mg} \mathrm{L}^{-1}\right)$, $\mathrm{NO}_{3}-\mathrm{N}\left(\mathrm{mg} \mathrm{L}^{-1}\right)$. Plant growth intensity (with a hand ruler) (n=6) and chlorophyll level of the leafs chosen randomly was weighed with a SPAD-502 Plus Chlorophyll Meter (Konica Minolta, Japan) once a week. The leaves were selected from the top, bottom and center of the plant $(n=3)$.

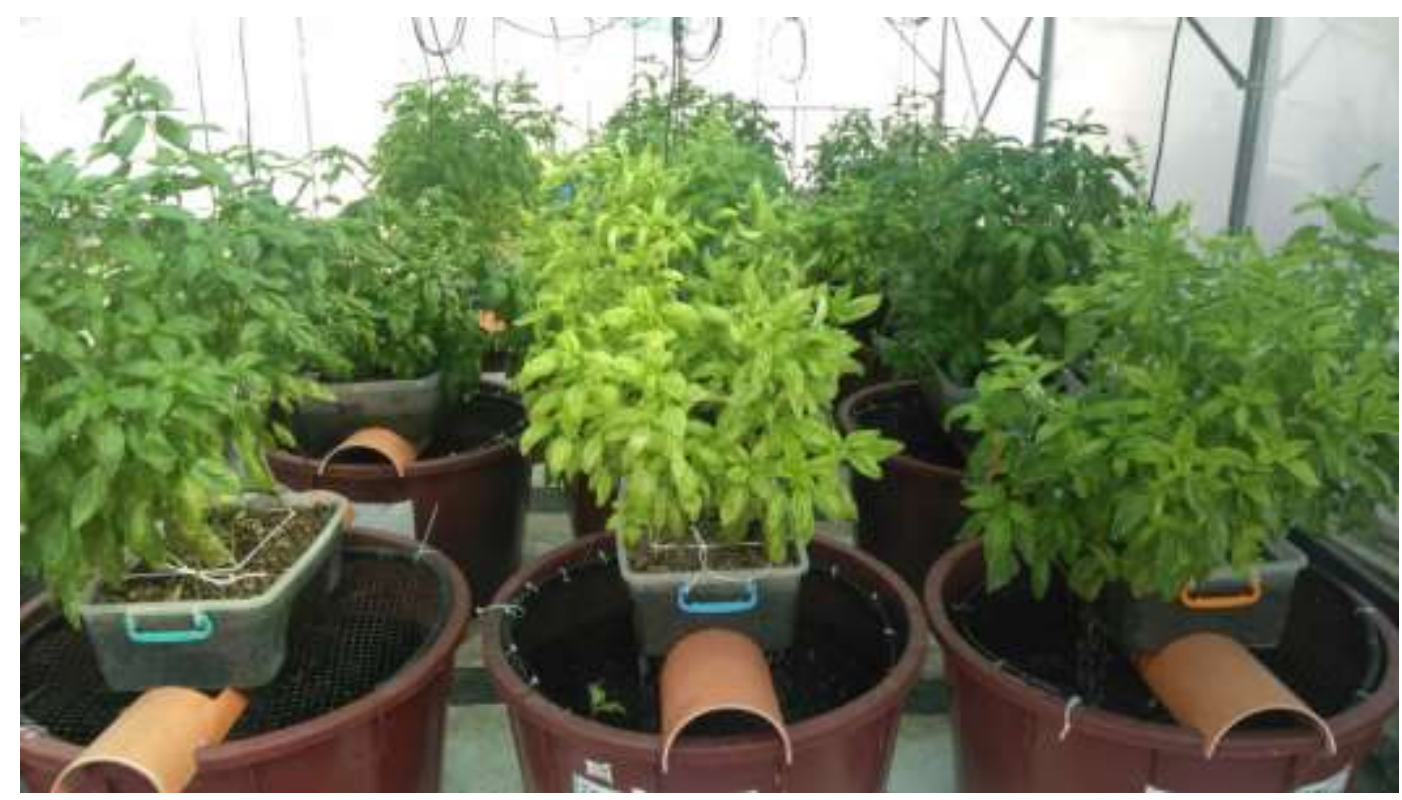

\section{Mathematical and Statistical analyses}

Fish growth parameters were calculated at the end of the experiment. Specific growth rate SGR $\left(\% \mathrm{~d}^{-1}\right)=$ $\left(\ln \mathrm{W}_{\mathrm{t}}-\ln \mathrm{W}_{0}\right) \times \mathrm{t}^{-1} \times 100$, where $\mathrm{W}_{\mathrm{t}}=$ final biomass, $\mathrm{W}_{0}=$ initial biomass, $\mathrm{t}=$ time in days (Pucher et al., 2015), Feed conversion ratio FCR $\left(\mathrm{g} \mathrm{g}^{-1}\right)=$ fish feed quantity $(\mathrm{g}) \times$ weight gain $(\mathrm{g})^{-1}$, Protein efficiency ratios PER $\left(\mathrm{g} \mathrm{g}^{-1}\right)=$ wet weight gain $(\mathrm{g}) /$ total protein intake $(\mathrm{g})$, Weight gain WG $(\%)=100 \times($ final body weight-initial body weight)/initial body weight. The data were analyzed with Microsoft Excel (2016) and statistical software package SPSS version 22. Variations in fish and plant growth as well as water quality parameters were determined with independent t-test $(\mathrm{P}<0.05)$.

\section{RESULTS}

Growth parameters of common carp (Table 1), final weight (unit $\mathrm{I}=188.63 \mathrm{~g} \pm 79.24$, unit $\mathrm{II}=198.71 \mathrm{~g} \pm$ 64.13 ), final biomass (unit $\mathrm{I}=2829.45 \mathrm{~g} \pm 79.24$, unit II $=2980.6 \mathrm{~g} \pm 64.13 \mathrm{~g}$ ), feed conversion ratio FCR (unit $\mathrm{I}=1.76 \pm 22.52$, unit $\mathrm{II}=1.44 \pm 0.36)$, protein efficiency ratios PER (unit $\mathrm{I}=1.03 \mathrm{~g} \mathrm{~g}^{-1} \pm 0.85$, unit II $=1.25 \mathrm{~g} \mathrm{~g}^{-1} \pm 0.27$ ), weight gain WG (unit $\mathrm{I}=33.9 \% \pm$ 28.02 , unit $\mathrm{II}=41.3 \% \pm 8.78$ ) and specific growth rate (SGR) showed no significant differences $(\mathrm{P}>0.05)$ between the treatments. The SGR (unit I $=0.50 \% \mathrm{~d}^{-1} \pm$ 0.39 , unit II $\left.=0.60 \% \mathrm{~d}^{-1} \pm 0.11\right)$ was better in unit II. No mortality was observed during the experiment.
Basil total biomass was higher in the unit II. $(5367.41 \mathrm{~g})$ than in unit I. (4254.9 g). Chlorophyll content of leaves showed significant difference $(\mathrm{P}<0.05)$ at young leaves. Plants of unit II. had more chlorophyll 35.59 ( \pm 5.04). Plant height (59.68 \pm 3.56 , $61.32 \pm 3.48)$, SPAD total $(32.20 \pm 8.39,36.07 \pm 7.53)$, SPAD of bottom leaves $(30.12 \pm 9.47,38.14 \pm 6.60)$, and SPAD of center leaves was not significantly different $(\mathrm{P}>0.05)$ (Table 2). Equation of plant height (Figure 3) showed better values in the unit. II $\left(y=8.1471 x+16.104, R^{2}=0.9321\right)$ than in the unit. I $\left(y=7.5674 x+19.86, R^{2}=0.9183\right)$.

The main difference was detected between the water quality parameters of fish tanks (Table 3). Significant differences $(\mathrm{P}<0.05)$ were observed in dissolved oxygen (DO) levels $5.55 \mathrm{mg} \mathrm{L}^{-1}$ ( \pm 1.6$)$; 6.30 $\mathrm{mg} \mathrm{L}^{-1}( \pm 1.0)$ (Figure 4), oxygen saturation $65.92 \%( \pm$ $18.2) ; 76.29 \%( \pm 11.1)$, and electric conductivity (EC) $729.20 \mu \mathrm{s} \mathrm{cm}^{-1}$ ( \pm 101.96$) ; 839.76 \mu \mathrm{s} \mathrm{cm}^{-1}$ ( \pm 204.05$)$. The higher values were measured in the fish rearing tanks of unit II. No significant differences $(\mathrm{P}<0.05)$ were observed in temperature $23.66^{\circ} \mathrm{C}( \pm 2.16) ; 24.20$ ${ }^{\circ} \mathrm{C}( \pm 2.11)$, redox potential (ORP) $124.5 \mathrm{mv} ; 110.4 \mathrm{mv}$ and $\mathrm{pH}(8.4( \pm 0.34) ; 8.4( \pm 0.31)$ of water. Levels of nitrite $\left(\mathrm{NO}_{2}-\mathrm{N}\right)$ were lower in fish tanks of unit II while ammonia $\left(\mathrm{NH}_{3}-\mathrm{N}\right) 1.01 \mathrm{mg} \mathrm{L}^{-1}( \pm 0.76) ; 0.90 \mathrm{mg} \mathrm{L}^{-1}( \pm$ $0.76)$ and nitrate $\left(\mathrm{NO}_{3}-\mathrm{N}\right) 3.98 \mathrm{mg} \mathrm{L}^{-1}( \pm 2.40) ; 3.68$ $\mathrm{mg} \mathrm{L}^{-1}( \pm 1.70)$ were not different $(\mathrm{P}>0.05)$. 
Figure 3. Mean weekly height of Basil (Ocimum basilicum) in aquaponics systems
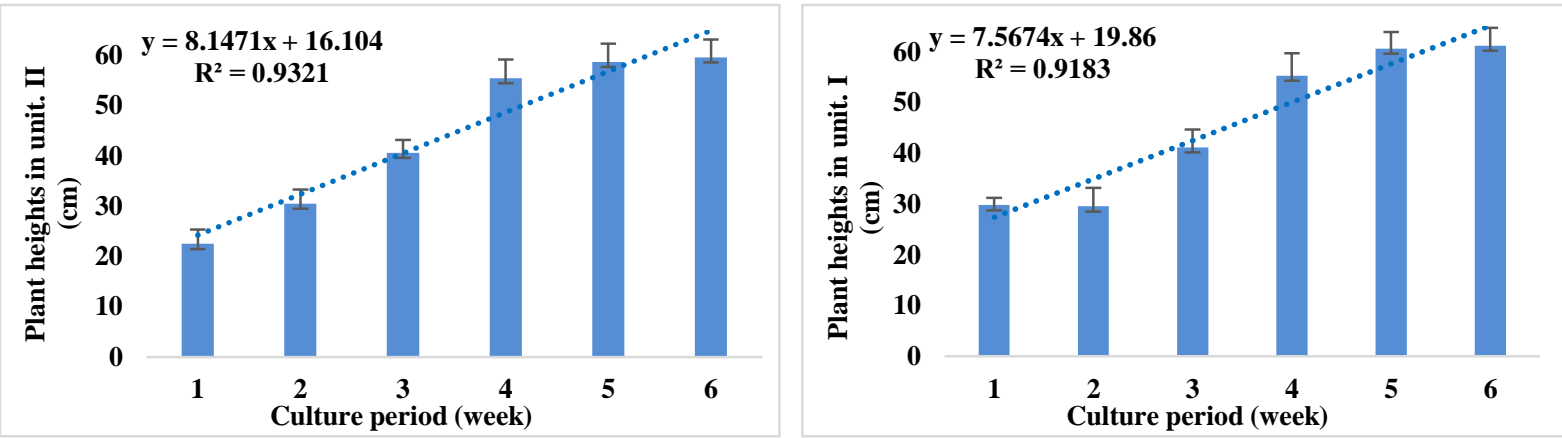

Table 1. Growth performance of the $\boldsymbol{C}$. carpio in the study

\begin{tabular}{ccc}
\hline Parameters & $\begin{array}{c}\text { Unit I } \\
\text { (aquaponics without air plump) }\end{array}$ & $\begin{array}{c}\text { Unit II } \\
\text { (aquaponics) }\end{array}$ \\
\hline Initial weight $(\mathrm{g})$ & $140.91^{\mathrm{a}} \pm 69.73$ & $140.57^{\mathrm{a}} \pm 30.23$ \\
Final weight $(\mathrm{g})$ & $188.63^{\mathrm{a}} \pm 79.24$ & $198.71^{\mathrm{a}} \pm 64.13$ \\
Initial biomass $(\mathrm{g})$ & $2113.6^{\mathrm{a}} \pm 69.73$ & $2108.55^{\mathrm{a}} \pm 30.23$ \\
Final biomass $(\mathrm{g})$ & $2829.45^{\mathrm{a}} \pm 79.24$ & $2980.6^{\mathrm{a}} \pm 64.13$ \\
SGR $\left(\% \mathrm{~d}^{-1}\right)$ & $0.50^{\mathrm{a}} \pm 0.39$ & $0.60^{\mathrm{a}} \pm 0.11$ \\
FCR $\left(\mathrm{g} \mathrm{g}^{-1}\right)$ & $1.76^{\mathrm{a}} \pm 22.52$ & $1.44^{\mathrm{a}} \pm 0.36$ \\
PER $\left(\mathrm{g} \mathrm{g}^{-1}\right)$ & $1.03^{\mathrm{a}} \pm 0.85$ & $1.25^{\mathrm{a}} \pm 0.27$ \\
WG $(\%)$ & $33.9^{\mathrm{a}} \pm 28.02$ & $41.3^{\mathrm{a}} \pm 8.78$ \\
\hline
\end{tabular}

Note: Mean values \pm SEM of fish parameters, significance $(\mathrm{P}<0.05)$.

Table 2. Basil (Ocimum basilicum) parameters

\begin{tabular}{ccc}
\hline Parameters & $\begin{array}{c}\text { Unit I } \\
\text { (aquaponics without air plump) }\end{array}$ & $\begin{array}{c}\text { Unit II } \\
\text { (aquaponics) }\end{array}$ \\
\hline Initial plant height $(\mathrm{cm})$ & $22.53^{\mathrm{a}} \pm 2.84$ & $21.98^{\mathrm{a}} \pm 1.40$ \\
Final plant height $(\mathrm{cm})$ & $59.68^{\mathrm{a}} \pm 3.56$ & $61.32^{\mathrm{a}} \pm 3.48$ \\
Total biomass $\left(\mathrm{kg} \mathrm{m}^{-2}\right)$ & 4.256 & 5.367 \\
Plant wet weight gain $\left(\mathrm{kg} \mathrm{m}^{-2}\right)$ & $1.77^{\mathrm{a}} \pm 0.20$ & $1.40^{\mathrm{a}} \pm 0.38$ \\
$\operatorname{SPAD}_{\text {(total) }}$ & $32.20^{\mathrm{a}} \pm 8.39$ & $36.07^{\mathrm{a}} \pm 7.53$ \\
$\operatorname{SPAD}_{\text {(top leafs) }}$ & $33.97^{\mathrm{a}} \pm 8.86$ & $35.59^{\mathrm{b}} \pm 5.04$ \\
$\operatorname{SPAD}_{\text {(center leafs) }}$ & $32.51^{\mathrm{a}} \pm 6.56$ & $34.47^{\mathrm{a}} \pm 10.01$ \\
$\operatorname{SPAD}_{\text {(bottom leafs) }}$ & $30.12^{\mathrm{a}} \pm 9.47$ & $38.14^{\mathrm{a}} \pm 6.60$ \\
\hline
\end{tabular}

Note: Mean values \pm SEM of plant parameters, significance $(\mathrm{P}<0.05)$.

Table 3. Water quality parameters

\begin{tabular}{ccc}
\hline Parameters & $\begin{array}{c}\text { Unit I } \\
\text { (aquaponics without air plump) }\end{array}$ & $\begin{array}{c}\text { Unit II } \\
\text { (aquaponics) }\end{array}$ \\
\hline Dissolved oxygen $\left(\mathrm{mg} \mathrm{L}^{-1}\right)$ & $5.55^{\mathrm{a}} \pm 1.6$ & $6.30^{\mathrm{b}} \pm 1.0$ \\
Oxygen saturation (\%) & $65.92^{\mathrm{a}} \pm 18.2$ & $76.29^{\mathrm{b}} \pm 11.1$ \\
Electric conductivity $\left(\mu \mathrm{s} \mathrm{cm}^{-1}\right)$ & $729.20^{\mathrm{a}} \pm 101.96$ & $839.76^{\mathrm{b}} \pm 204.05$ \\
Temperature $\left({ }^{\circ} \mathrm{C}\right)$ & $23.66^{\mathrm{a}} \pm 2.16$ & $24.20^{\mathrm{a}} \pm 2.11$ \\
Redox potential (mv) & $124.5^{\mathrm{a}}$ & $110.4^{\mathrm{a}}$ \\
$\mathrm{pH}$ & $8.4^{\mathrm{a}} \pm 0.34$ & $8.4^{\mathrm{a}} \pm 0.31$ \\
$\mathrm{NH}-\mathrm{N}\left(\mathrm{mg} \mathrm{L}^{-1}\right)$ & $1.01^{\mathrm{a}} \pm 0.76$ & $0.90^{\mathrm{a}} \pm 0.76$ \\
$\mathrm{NO}_{2}-\mathrm{N}\left(\mathrm{mg} \mathrm{L}^{-1}\right)$ & $1.82^{\mathrm{a}} \pm 3.28$ & $0.55^{\mathrm{b}} \pm 1.17$ \\
$\mathrm{NO}_{3}-\mathrm{N}\left(\mathrm{mg} \mathrm{L}^{-1}\right)$ & $3.98^{\mathrm{a}} \pm 2.40$ & $3.68^{\mathrm{a}} \pm 1.70$ \\
\hline
\end{tabular}

Note: Mean values \pm SEM of water quality parameters, significance $(\mathrm{P}<0.05)$. 
Figure 4. Changes in oxygen levels during the experiment

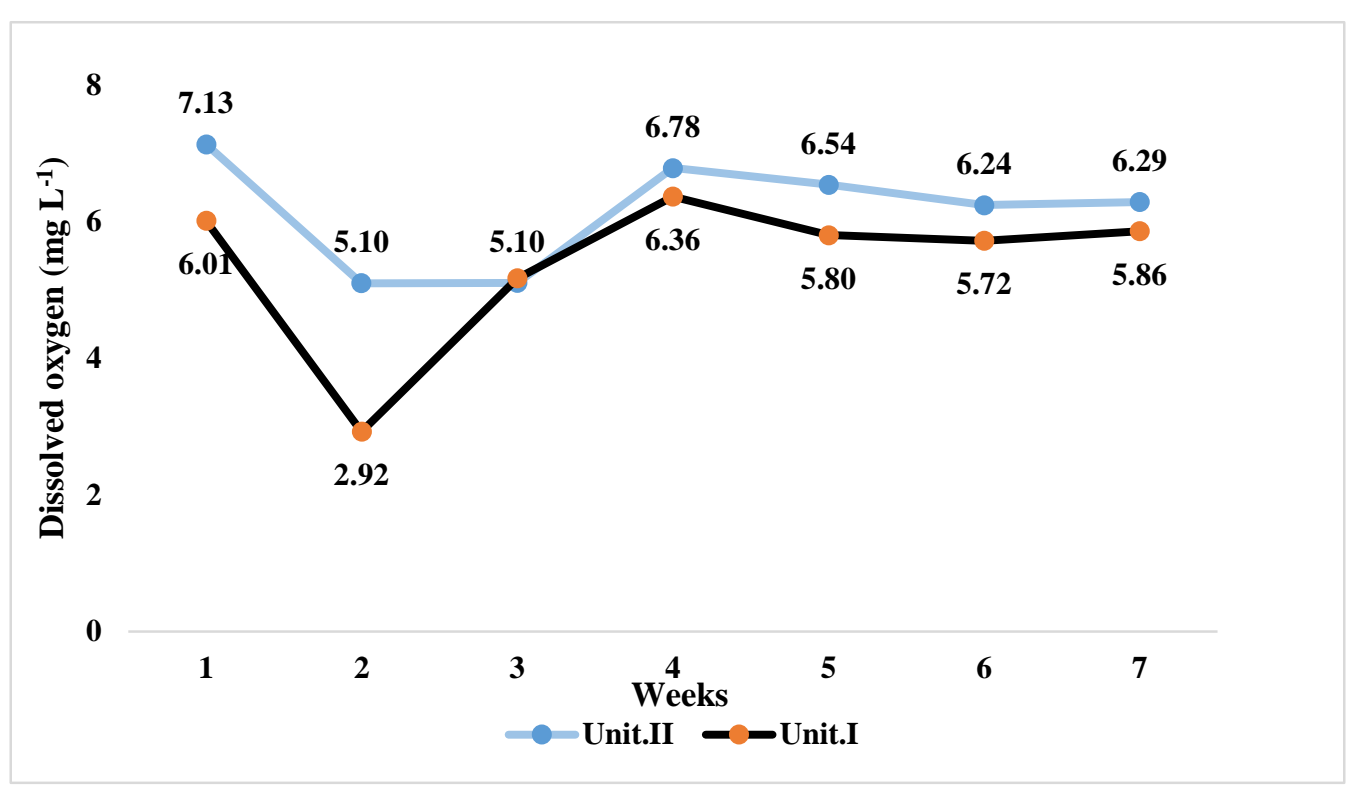

\section{DISCUSSION}

The present study describes effect of the low oxygen level on water parameters, carp and basil growth. The presence and proportion of nitrogen forms is determined by the amount of oxygen ( $\mathrm{Hu}$ et al., 2015). The EC (electrical conductivity) determine the quantity of nitrogen ions dissolved in water. This nutrient source basically determines plant growth.

No fish mortality was recorded during the experimental period. The water quality was adequate for carp growth in both systems. The carp is well adapted to lower oxygen levels (Somogyi et al., 2019). Sometimes there were extremely low dissolved oxygen levels during the experiment, but it did not lead to fish death. The feed conversion ratios (FCR) of common carp were $1.76 \mathrm{~g} \mathrm{~g}^{-1}$ and $1.44 \mathrm{~g} \mathrm{~g}^{-1}$ in the study. Paudel,
(2020) reported similar FCR values of $1.73-1.75 \mathrm{~g} \mathrm{~g}^{-1}$ at $C$. carpio after 125 days. Shete et al. (2016) published better feed conversion ratio of $1.06 \mathrm{~g} \mathrm{~g}^{-1}$ with initial and final weight $0.30-8.07 \mathrm{~g}$ at $6.5 \mathrm{mg} \mathrm{L}^{-1}$ dissolved oxygen after 2 months. Majeed and Najim, (2019) reported higher $2.01 \mathrm{~g} \mathrm{~g}^{-1}$ feed conversion ratio in their experiment with 41.3-48.42 $\mathrm{g}$ initial and final weight at $5.36 \mathrm{mg} \mathrm{L}^{-1}$ oxygen after 60 days. Specific growth rate (SGR) for unit II $\left(0.60 \% \mathrm{~d}^{-1}\right)$ was better in the present experiment. Majeed and Najim, (2019) published lower SGR values. The experiment was conducted with $C$. carpio in aquaponics system with $0.26 \% \mathrm{~d}^{-1} \mathrm{SGR}$ as a result. The dissolved oxygen level was $5.36 \mathrm{mg} \mathrm{L}^{-1}$ in the fish tank, during the experiment (60 days). The relationship between oxygen and SGR values in the literature is shown in Table 4 as a function of stocking density and duration.

Table 4. SGR values in common and Koi carp reared in aquaponics systems

\begin{tabular}{|c|c|c|c|c|c|}
\hline Fish species & DO $\left(\mathrm{mg} \mathrm{L}^{-1}\right)$ & $\operatorname{SGR}\left(\% \mathbf{d}^{-1}\right)$ & $\begin{array}{l}\text { Stocking density } \\
\qquad\left(\mathrm{kg} \mathrm{m}^{-3}\right)\end{array}$ & $\begin{array}{c}\text { Time of } \\
\text { experiment } \\
\text { (day) }\end{array}$ & Reference \\
\hline common carp & $6.0-7.0$ & $0.2-0.3$ & 10 & 52 & Zou et al. (2016) \\
\hline common carp & 6.3 & 0.39 & 12.2 & 70 & Knaus and Palm (2017) \\
\hline common carp & $5.7-6.6$ & $5.4-5.5$ & 0.18 & 60 & Shete et al. (2016) \\
\hline common carp & $6.8-6.9$ & $0.8-1.0$ & 4.6 & 30 & Sirakov et al. (2018) \\
\hline common carp & $6.4-6.6$ & $1.4-2.0$ & 5 & 40 & Sirakov and Velichkova (2018) \\
\hline Cyprinus carpio var. Koi & $5.6-6.8$ & $0.3-0.8$ & 2.8 & 60 & Hussain et al. (2015) \\
\hline Cyprinus carpio var. Koi & $5.4-6.7$ & $0.7-0.9$ & 1.4 & 60 & Nuwansi et al. (2019) \\
\hline
\end{tabular}

Plant biomass of basil was $4 \mathrm{~kg} \mathrm{~m}^{-2}\left(5.5 \mathrm{mg} \mathrm{L}^{-1}\right.$, DO; $65,9 \mathrm{O}_{2} \% ; 0.73 \mathrm{mS} \mathrm{cm}{ }^{-1}, \mathrm{EC} ; 1 \mathrm{mg} \mathrm{L}^{-1}, \mathrm{NH}_{3}-\mathrm{N} ; 1.8$ $\left.\mathrm{mg} \mathrm{L}^{-1}, \mathrm{NO}_{2}-\mathrm{N} ; 3.98 \mathrm{mg} \mathrm{L}^{-1}, \mathrm{NO}_{3}-\mathrm{N}\right)$ and $5 \mathrm{~kg} \mathrm{~m}^{-2}(6.3$ $\mathrm{mg} \mathrm{L}{ }^{-1}$, DO; $76.2 \%, 0.84 \mathrm{mS} \mathrm{cm}{ }^{-1}$, EC; $0.9 \mathrm{mg} \mathrm{L}^{-1}$, $\left.\mathrm{NH}_{3}-\mathrm{N} ; 0.55 \mathrm{mg} \mathrm{L}^{-1}, \mathrm{NO}_{2}-\mathrm{N} ; 3.68 \mathrm{mg} \mathrm{L}^{-1}, \mathrm{NO}_{3}-\mathrm{N}\right)$ at the end of the experiment. Basil height grew from 22.5 $\mathrm{cm}$ to $59.6 \mathrm{~cm}$ (in Unit I) and from $21.9 \mathrm{~cm}$ to $61.3 \mathrm{~cm}$ (in Unit II) in 42 days. Rakocy et al. (2004) reported the basil yield over $2 \mathrm{~kg} \mathrm{~m}^{-2}$ per harvest (28 days) beside 4-5 mg L-1 (DO), $0.8 \mathrm{mS} \mathrm{cm}^{-1}$ (EC). The nitrogen forms 
were $2 \mathrm{mg} \mathrm{L}^{-1}$, TAN; $1 \mathrm{mg} \mathrm{L}^{-1}>, \mathrm{NO}_{2}-\mathrm{N} ; 42 \mathrm{mg} \mathrm{L}^{-1}$, $\mathrm{NO}_{3}-\mathrm{N}$ in the aquaponics system. Other aquaponics studies using basil reported yields of $0.531 \mathrm{~kg} \mathrm{~m}^{-2}$ biomass production (over 30 days), where water parameters were 4-6 $\mathrm{mg} \mathrm{L}^{-1}$ (dissolved oxygen), 0.6$0.9 \mathrm{mS} \mathrm{cm}^{-1}$ (electrical conductivity) and $0.1-0.4$ $\mathrm{mg} \mathrm{L}{ }^{-1}, \mathrm{NH}_{4} ; 0.3 \mathrm{mg} \mathrm{L}^{-1}, \mathrm{NO}_{2} ; 10-12 \mathrm{mg} \mathrm{L}^{-1}, \mathrm{NO}_{3}$ (Espinosa et al., 2016). Dissolved oxygen 6.5-7.5

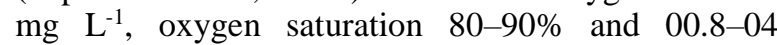
$\mathrm{mg} \mathrm{L}{ }^{-1}, \mathrm{NH}_{4} ; 0.05-0.2 \mathrm{mg} \mathrm{L}^{-1}, \mathrm{NO}_{2} ; 11-106 \mathrm{mg} \mathrm{L}^{-1}$, $\mathrm{NO}_{3}$ were in the aquaponics system where basil production was $5 \mathrm{~kg} \mathrm{~m}^{-3}$ at final harvest, and length of plants changed from $27 \mathrm{~cm}$ to $131 \mathrm{~cm}$ in 5 weeks during the experiment (75 days) of Selek et al. (2015). Lower basil lengths were measured by Saha et al. (2016). The plants mean height was $90 \mathrm{~cm}$ in the aquaponics system.

The chlorophyll content in the present study were higher in unit II. Saha et al., (2016) analyzed SPAD index of basil leaf in aquaponics. Different results were observed in the SPAD values. Mean of basil leaves chlorophyll content was not reaching 30 SPAD reading. As well lower SPAD values were measured by Rakocy and Hargeaves (1993).

The water parameters were favorable for carp in both units. Dissolved oxygen level of unit I was decreasing during the one-week acclimatization period for the fish $\left(2.92 \mathrm{mg} \mathrm{L}^{-1}\right)$. Then 30 percent of water change was applied and faster water flow was provided in the unit I. From the first week of the experiment oxygen values were over $5 \mathrm{mg} \mathrm{L}^{-1}$ and it did not go lower during the whole duration. Knaus and Palm, (2017) reported similar oxygen distribution. The dissolved oxygen level decreased until day 10 of the experiment (phase I), then increased in the middle phase from day 12. Zou et al. (2016) and Stoyanova et al. (2020) reported similar mean DO values too.
Oxygen content in the fish tank was measured in aquaponics system in summer the mean was $6 \mathrm{mg} \mathrm{L}^{-1}$ during the experiment. The optimum oxygen level was between 5-6 $\mathrm{mg} \mathrm{L}^{-1}$ by Bernstein, (2011).

The electrical conductivity (EC) was lower in unit I $\left(729.20 \mu \mathrm{s} \mathrm{cm}^{-1}\right)$, it refers to better mineral use by plants. Knaus and Palm (2017) published different results when Carp was reared in aquaponics. The EC was $588.8 \mu \mathrm{s} \mathrm{cm}^{-1}$.

The redox potential (ORP) affects biological and chemical processes of the water. (Ge et al., 2015). Wang et al. (2015) demonstrated that the decrease of ORP is related to the decrease of dissolved oxygen (DO). Therefore, the ORP affects low NH4 + contents through oxygen. The redox potential of fish tanks was lower in the unit II equipped with air pump (124.5 mv) where dissolved oxygen level was higher $(6.30 \pm 1.0)$ that in the unit I $(5.55 \pm 1.6)$. Similar results were published with Nile tilapia (Oreochromis niloticus) and common carp (Cyprinus carpio) by Knaus and Palm (2019) at $5.8 \mathrm{mg} \mathrm{L}^{-1}$ oxygen the ORP $123.6 \mathrm{mv}(O$. niloticus) in aquaponics. At other treatment ORP was $121.4 \mathrm{mv}$ and DO $6.3 \mathrm{mg} \mathrm{L}^{-1}$ in fish tanks.

The nitrite levels were different. The mean lower oxygen level $\left(5.55 \mathrm{mg} \mathrm{L}^{-1}\right)$ affected higher mean $\mathrm{NO}_{2-}$ $\mathrm{N}\left(1.82 \mathrm{mg} \mathrm{L}^{-1}\right)$ in unit I. Extreme high values were detected in both units during the beginning of the experiment (Figure 5). Results of Paudel (2020) where the Nitrogen transformation was examined in aquaponics, higher nitrite levels were observed during the first of the three parts of the experiment. Wongkiew et al. (2017) examined the effect of the oxygen levels on the nitrification and demonstrated that the nitrite oxidation was affected by low dissolved oxygen conditions. This is also supported by the changes in nitrite concentrations.

Figure 5. Change of nitrite values $\left(\mathrm{mg} \mathrm{L}^{-1}\right)$ as a function of oxygen

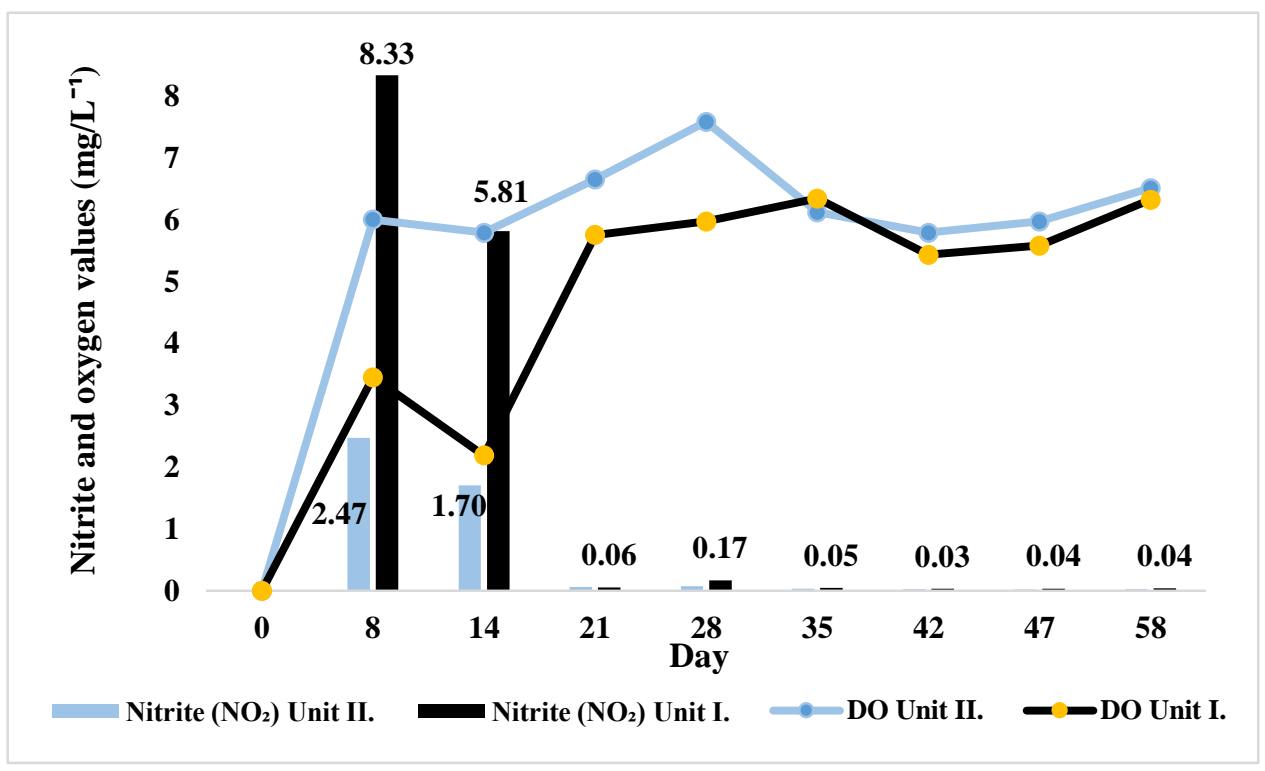




\section{CONCLUSIONS}

The dissolved oxygen quantity is very important in the aquaponics systems. It is essential not only for fish but also for the optimum status of other water quality parameters. Results in the present study pointed out that oxygen level has a direct impact on nitrification, fish production parameters, nutrient uptake by plants and, as a result leads to increase in plant and fish biomass. The results show that basil (Ocimum basilicum) production can be combined with common carp (Cyprinus carpio). It proved to be environmentally sustainable at lower dissolved oxygen levels. Furthermore, there is an alternative to bypass the air pump, which can provide more cost effective operation in aquaponics.

\section{ACKNOWLEDGEMENTS}

This work was supported by 2018-1.3.1-VKE2018-00012 project: "An Environmental and Economic Improvement of Input and Output Parameters of Closed Aquaculture Systems".

\section{REFERENCES}

Baßmann, B.-Brenner, M.-Palm, H.W. (2017): Stress and Welfare of African Catfish (Clarias gariepinus Burchell, 1822) in a Coupled Aquaponic System. Water MDPI 9, 504; doi:10.3390/w9070504

Bernstein, S. (2011): Aquaponic Gardening: A Step-by-Step Guide to Raising Vegetable and Fish Together. New Society Publishers, Grabiola, Canada.

Diver, S. (2006): Aquaponics - Integration of Hydroponics with Aquaculture. ATTRA Natl. Sustain. Agric. Infromation Serv. https://doi.org/10.1146/annurev.genet.37.110801.143717

Ebeling, J.M.-Timmons, M.B.-Bisogni, J.J. (2006): Engineering analysis of the stoichiometry of photoautotrophic, autotrophic, and heterotrophic removal of ammonia-nitrogen in aquaculture systems. Aquaculture, 257, 346-358.

El-Sayed, A.F.M. (2006) Tilapia Culture. CAB eBooks, Oceanography Department, Faculty of Science, Alexandria University, Alexandria, Egypt. https://doi.org/101079/9780851990149.0000

Espinosa Moya, E.A.-Angel Sahagún, C.A.-Mendoza Carrillo, J.M.-Albertos Alpuche, P.J.-Álvarez-González, C.A.Martínez-Yáñez, R. (2016): Herbaceous plants as part of biological filter for aquaponics system. Aquacult.Res., 47, 17161726.

Estim, A.-Saufie, S.-Mustafa, S. (2019): Water quality remediation using aquaponics sub-systems as biological and mechanical filters in aquaculture. Journal of Water Process Engineering, 30, 100566

Ge, S.-Wang, S.-Yang, X.-Qiu, S.-Li, B.-Peng, Y. (2015): Detection of nitrifiers and evaluation of partial nitrification for wastewater treatment: A review. Chemosphere. 140, 85-98.

Graber, A.-Junge, R. (2009): Aquaponic Systems: Nutrient recycling from fish wastewater by vegetable production. Desalination, 246, 147-156.

Love, D.C.-Fry, J.P.-Li, X.-Hill, E.S.-Genello, L.-Semmens, K.Thompson, R.E. (2015): Commercial aquaponics production and profitability: Findings from an international survey. Aquaculture, 435, 67-74.

Hussain, T.-Verma, A.-Tiwari, V.-Prakash, C.-Rathore, G.-Shete, A.-Saharan, N. (2015): Effect of water flow rates on growth of Cyprinus carpio var. koi (Cyprinus carpio L., 1758) and spinach plant in aquaponic system. Aquacult.Int., 23, 369-384.

Hu, Z.-Lee, J.W.-Chandran, K.-Kim, S.-Brotto, A.C.-Khanal, S.K. (2015): Effect of plant species on nitrogen recovery in aquaponics. Bioresource Technology, 188, 92-98.

Hu, Z.-Lee, J.W.-Chandran, K.-Kim, S.-Sharma, K.-Khanal, S.K. (2014): Influence of carbohydrate addition on nitrogen transformations and greenhouse gas emissions of intensive aquaculture system. Science of The Total Environment, 470471, 193-200.

Kasozi, N.-Tandlich, R.-Fick, M.-Kaiser, H.-Wilhelmi, B. (2019): Iron supplementation and management in aquaponic systems: A review. Aquaculture Reports, 15, 100221.

Knaus, U.-Palm, H. (2017): Effects of the fish species choice on vegetables in aquaponics under spring-summer conditions in northern germany (mecklenburg western pomerania). Aquaculture. 473, 62-73.

Kurd, F.-Fathi, M.-Shekarchizadeh, H. (2017): Basil seed mucilage as a new source for electrospinning: Production and physicochemical characterization. Int.J.Biol.Macromol., 95, 689-695.

Mangmang, J.S.-Deaker, R.-Rogers, G. (2016): Inoculation effect of Azospirillum brasilense on basil grown under aquaponics production system. Organic agriculture, 6, 65-74.

Mostafavi, S.-Asadi-Gharneh, H.A.-Miransari, M. (2019): The phytochemical variability of fatty acids in basil seeds (Ocimum basilicum L.) affected by genotype and geographical differences. Food Chem., 276, 700-706.

Najim Haider, S.-Majeed Salah, M. (2019): Growth of common carp (Cyprinus carpio) in developed aquaponic system.

Nuwansi, K.K.T.-Verma, A.K.-Rathore, G.-Prakash, C.Chandrakant, M.H.-Prabhath, G.P.W.A. (2019): Utilization of phytoremediated aquaculture wastewater for production of koi carp (Cyprinus carpio var. koi) and gotukola (Centella asiatica) in an aquaponics. Aquaculture 507: 361-369.

Panuvatvanich, A.-Koottatep, T.-Kone, D. (2009): Influence of sand layer depth and percolate impounding regime on nitrogen transformation in vertical-flow constructed wetlands treating faecal sludge. Water Research, 43, 2623-2630.

Paudel, S.R. (2020): Nitrogen transformation in engineered aquaponics with water celery (Oenanthe javanica) and koi carp (Cyprinus carpio): Effects of plant to fish biomass ratio. Aquaculture 520:734971.

Pucher, J.-Mayrhofer, R.-El-Matbouli, M.-Focken, U. (2015): Pond management strategies for small-scale aquaculture in northern Vietnam: fish production and economic performance. Aquacult Int 23:297-314

Roosta, H.R. (2014): Comparison of the vegetative growth, ecophysiological characteristics and mineral nutrient content of basil plants in different irrigation ratios of hydroponic: aquaponic solutions. J.Plant Nutr., 37, 1782-1803.

Rakocy, J. (2007): Ten Guidelines for Aquaponic Systems. Aquaponics J. 3rd Quarte, 14-17. 
Rakocy, J.E.-Hargreaves, J.A. (1993): Integration of vegetable hydroponics with fish culture: a review. In: Wang, J.K. (Ed.), Techniques for Modern Aquaculture. Am. Soc. Agric Engineers, St. Joseph, MI, USA, pp. 112-136.

Rakocy, J.E.-Masser, M.P.-Losordo, T.M. (2006): Recirculating Aquaculture Tank Production Systems: Aquaponics Integrating Fish and Plant Culture. SRAC Publ, p. 454.

Lukowicz, M.V. (1982): Intensive carp Cyprinus carpio (L.) rearing in a farm pond in southern Germany and its effects on water quality. Aquacultural Engineering, 1, 121-137.

Saha, S.-Monroe, A.-Day, M.R. (2016): Growth, yield, plant quality and nutrition of basil (Ocimum basilicum L.) under soilless agricultural systems. Annals of Agricultural Sciences, 61, 181186.

Selek, M.-Endo, M.-Yiğit, M.-Takeuchi, T. (2015): The integration of fish and plant production: Nile tilapia (Oreochromis niloticus) and basil (Ocimum basilicum) culture in recirculating and aquaponic systems. Journal of Aquaculture Engineering and Fisheries Research, 3, 28-43.

Shete, A.-Verma, A.-Chadha, N.-Prakash, C.-Peter, R.-Ahmad, I.Nuwansi, K.K.T. (2016): Optimization of hydraulic loading rate in aquaponic system with Common carp (Cyprinus carpio) and Mint (Mentha arvensis). Aquacult Eng 72:53-57.

Sirakov, I.-Velichkova, K. (2018): The influence of aquaponically grown duckweed (Lemna minuta Kunth) used for composition of sustainable diets on hydrochemical and technological parameters in carp (Cyprinus carpio L.). Turkish Journal of Fisheries and Aquatic Sciences 18: 1037-1044.

Sirakov, I.-Velichkova, K.-Stoyanova, S.-Kaymakanova, M.Slavcheva-Sirakova, D.-Atanasova, R.-Staykov, Y. (2018): Effect of synbiotic dietary supplementation on growth, physiological and immunological parameters in common carp (Cyprinus carpio L.) fingerlings and on yield and physiological parameters in lettuce (Lactuca sativa L.), cultivated in mesocosmos aquaponic system. Bulgarian Journal of Agricultural Science 24: 140-149.
Somerville, C.-Cohen, M.-Pantanella, E.-Stankus, A.--Lovatelli, A. (2014): Small-scale aquaponic food production. Integrated fish and plant farming. FAO Fisheries and Aquaculture Technical Paper No. 589. FAO, Rome (262 pp).

Somogyi, D.-Farkas, Gy.-Deák, S.-Nagy, S.A.-Nyeste, K.-Antal, L. (2019): A ponty (Cyprinus carpio) és az ezüstkárász (Carassius gibelio) kondíciójának vizsgálata egy termálvízzel ellátott állóvízi környezetben. PISCES HUNGARICI 13: 75-80.

Stoyanova, S.-Georgieva, E.-Velcheva, I.-Iliev I.-Vasileva, T.Bivolarski, V.-Tomov, S.-Nyeste, K.-Antal, L.-Yancheva, V. (2020): Multi-biomarker assessment in common carp (Cyprinus carpio, Linnaeus 1758) liver after acute chlorpyrifos exposure. Water 12: 1837

Tyson, R.V.-Simonne, E.H.-Treadwell, D.D.-White, J.M.Simonne, A. (2008): Reconciling $\mathrm{pH}$ for ammonia biofiltration and cucumber yield in a recirculating aquaponic system with perlite biofilters. HortScience, 43, 719-724.

Wang, K.-Li, W.-Li, X.-Ren, N. (2015): Spatial nitrifications of microbial processes during composting of swine, cow and chicken manure. Scientific reports. 5, 14932.

Wongkiew, S.-Popp, B.N.-Kim, H.-Khanal, S.K. (2017): Fate of nitrogen in floating-raft aquaponic systems using natural abundance nitrogen isotopic compositions. Int. Biodeterior. Biodegrad. 125, 24-32.

Zou, Y.-Hu, Z.-Zhang, J.-Xie, H.-Guimbaud, C.-Fang, Y. (2016): Effects of $\mathrm{pH}$ on nitrogen transformations in media-based aquaponics. Bioresour. Technol. 210, 81-87. 